\title{
PRINSIP-PRINSIP MANAJEMEN PENDIDIKAN DALAM HADIS
}

\author{
Hairul Hudaya \\ Fakultas Tarbiyah dan Keguruan IAIN Antasari Banjarmasin \\ Telp. (0511) 3252829, e-mail: hud_hud05@yahoo.com
}

\begin{abstract}
The Prophet Muhammad Saw has a great influence among his best friends. The influence was also felt in the field of management education. In management, there are four principles: planning, organizing, actuating and controlling. These four elements are then adopted in managing educational institutions which so called educational management. These four principles are also found in the prophetic spirit. In the beginning of the reign of the Prophet Muhammad in Medina, he launched a literacy program for the companions which was followed by the instructions to the particular person to learn certain science. The Prophet also established teaching and learning for all his followers. During the study, he often asked questions to know how far the companions' mastery of the material being taught. What the Prophet did can be categorized as a principle of prophetic management based education.
\end{abstract}

Kata kunci: Manajemen Pendidikan, Planning, Organizing

\section{Pendahuluan}

Menarik membaca analisis Michael Heart terkait penempatan Nabi Muhammad sebagai orang nomor satu paling berpengaruh di banding manusia lainnya yang pernah ada dan lahir di muka bumi. Sebagian bertanya, mengapa tidak Yesus yang ditempatkan diperingkat pertama? Bukankah umat Kristiani jumlahnya lebih banyak di banding umat Muslim. Saat buku tersebut ditulis, katanya, umat Kristiani berjumlah lebih dari 1 milyar sedang umat Muslim hanya berjumlah 500 juta. Bila dari segi jumlah pengikut mestinya Yesus menempati orang yang paling berpengaruh versi Hart karena memiliki banyak pengikut. Namun karena buku tersebut, menurutnya, membahas orang yang paling berpengaruh dan tidak pada jumlah pengikut maka jelas Nabi Muhammad lebih berpengaruh bagi pengikutnya di banding Yesus. Nabi Muhammad memainkan peran yang jauh lebih penting dalam perkembangan 
Islam ketimbang Yesus dalam perkembangan Nasrani. Dalam Islam, Nabi Muhammad bertanggung jawab terhadap teologi Islam maupun prinsip moral dan etikanya di samping beliau juga berperan penting dalam menyebarkan Islam dan membentuk praktik religius. Berbeda dengan Kristen, Paulus lebih berperan dalam mengembangkan, menyebarkan dan menulis sebagian besar perjanjian Baru. ${ }^{1}$

Pengaruh Nabi Muhammad tersebut juga sangat terasa dalam aspek pendidikan. Para sahabat sangat antusias dalam mengikuti pengajaran yang beliau berikan. Dikisahkan, misalnya, 'Umar ibn al-Khaththab yang tidak ingin tertinggal satu pengajian pun dari Nabi sampai terpaksa bergiliran dengan tetangganya untuk menghadiri pengajian tersebut. Apabila 'Umar hadir pada hari ini maka tetangganya hadir pada esok hari. Sesudah selesai pengajian, yang hadir pada saat itu memberitahu tentang materi yang disampaikan Nabi. Demikian pula sebaliknya. Ini menunjukkan bahwa kharisma, wibawa dan pengaruh Nabi sangat besar di mata sahabatnya. ${ }^{2}$

Dalam ilmu manajemen modern, keberhasilan seorang pemimpin tidak lepas dari kepiawannya dalam memanaj dan mengelola seluruh potensi anggotanya. Penyebaran agama Islam yang begitu luas dengan berbasis pada literasi dan bukan keberhasilan Nabi dalam mendorong para sahabat untuk belajar. Padahal sebelum masa kenabian, masyarakat Arab dikenal sebagai masyarakat ummi yang tidak pandai baca tulis. Apabila keberhasilan pemimpin sangat ditentukan dengan kemampuan menajerialnya maka tentunya keberhasilan Nabi dalam bidang pengajaran mengandung unsur manajemen yang perlu diteliti sehingga diketahui bagaimana beliau memanajnya. Makalah ini berusaha mengkaji prinsip manajemen pendidikan Nabi yang terdapat dalam berbagai riwayat dengan menyandingkannya pada prinsip manajemen pendidikan modern.

\section{Pengertian Manajemen}

Kata manajemen berasal dari Bahasa Latin, yaitu dari asal kata manus yang berarti tangan dan agere yang berarti melakukan. Kata-kata itu digabung menjadi kata kerja manager yang artinya menangani. Manager diterjemahkan ke

${ }^{1}$ Lihat, Michael H. Hart, The 100: A Ranking of the Most Influential Persons in History, diterjemahkan oleh Ken Ndaru dan M. Nurul Islam, 100 Tokoh Paling Berpengaruh di Dunia (Jakarta: Noura Books, 2012), h. 1-9.

${ }^{2}$ Lihat, Abu 'Abdullah Muhammad ibn Isma'il al-Bukhari, Shabih al-Bukhari (Beirut: Dar Ibn Katsir, 2002/1423), h. 35. 
dalam Bahasa Inggris dalam bentuk kata kerja to manage yang berarti mengurus, mengatur, melaksanakan dan mengelola. Dari kata tersebut muncul kata benda managemen, dan manager untuk orang yang melakukan kegiatan manajemen. Akhirnya, management diterjemahkan ke dalam Bahasa Indonesia menjadi manajemen atau pengelolaan. Manajemen sendiri, dalam Kamus Bahasa Indonesia, diartikan dengan 'proses pemakaian sumber daya secara efektif untuk mencapai sasaran yang telah ditentukan atau penggunaan sumber daya secara efektif untuk mencapai sasaran. ${ }^{3}$ Menurut Parker, pengertian manajemen ialah seni melaksanakan pekerjaan melalui orang-orang. Adapun pengertian manajemen dalam arti luas adalah perencanaan, pengorganisasian, pengarahan dan pengendalian (P4) sumber daya organisasi untuk mencapai tujuan secara efektif dan efisien. ${ }^{4}$

Pada prinsipnya, dasar manajemen terdiri dari perencanaan (planning), perorganisasian (organizing), penggerakan (actuating) dan pengawasan (controlling). Berikut adalah penjelasan masing-masing prinsip manajemen tersebut.

Perencanaan menurut G.R. Terry adalah kegiatan memilih dan menghubungkan fakta dan menggunakan sejumlah asumsi mengenai masa datang dengan jalan menggambarkan dan merumuskan kegiatan-kegiatan yang diperlukan untuk mencapai hasil yang diinginkan. Louis A. Allen mendefinisikan perencanaan dengan menentukan serangkaian tindakan untuk mencapai hasil yang diinginkan. Dari kedua definisi tersebut dapat dipahami bahwa perencanaan merupakan pekerjaan mental untuk memilih sasaran, kebijakan, prosedur dan program yang diperlukan untuk mencapai apa yang diinginkan pada masa yang akan datang. ${ }^{5}$ Berdasarkan definisi tersebut ada beberapa unsur dalam perencanaan: (1) sejumlah kegiatan yang ditetapkan sebelumnya, (2) adanya proses, (3) hasil yang ingin dicapai, dan (4) menyangkut masa depan dalam waktu tertentu. ${ }^{6}$

Organisasi berasal dari bahasa Latin, organum yang berarti alat, bagian, anggota badan. Menurut Handoko, pengorganisasian adalah 1) penentuan sumber daya dan kegiatan yang dibutuhkan untuk mencapai tujuan organisasi;

\footnotetext{
3Pusat Bahasa Departemen Pendidikan Nasional, Kamus Bahasa Indonesia Jakarta: Pusat Bahasa, 2008), h. 979.

${ }^{4}$ Husaini Usman, Manajemen: Teori, Praktik, dan Riset Pendidikan (Ed. 3; Jakarta: Bumi Aksara, 2011), h. 5. 2009), h. 97.

${ }^{5}$ Syahrizal Abbas, Manajemen Perguruan Tinggi Beberapa Catatan (Cet. 2; Jakarta: Kencana,

${ }^{6}$ Husaini Usman, Manajemen ..., h. 66.
} 
2) proses perancangan dan pengembangan suatu organisasi yang akan dapat membawa hal-hal tersebut ke arah tujuan; 3) penugasan tanggung jawab tertentu; 4) pendelegasian wewenang yang diperlukan kepada individu-individu untuk melaksanakan tugas-tugasnya. Menurut Sutarto, organisasi adalah kumpulan orang, proses pembagian kerja, dan system kerja sama atau system social. ${ }^{7}$ Pengorganisasian berfungsi untuk mengisi staf yang sesuai dengan tugas dan kedudukannya. ${ }^{8}$

Ada beberapa prinsip yang digunakan dalam melakukan kegiatan pengorganisasian, di antaranya adalah: (1) Prinsip perumusan tujuan secara jelas dan tepat; (2) Prinsip departementalisasi dan pembagian kerja; (3) Prinsip pelimpahan wewenang; (4) Prinsip kesatuan perintah; (5) Prinsip jenjang organisasi; (6) Prinsip kesinambungan dan keseimbangan; (7) Prinsip kelenturan; (8) Prinsip koordinasi; (9) Prinsipsa rentangan pengawasan. ${ }^{9}$

Penggerakan (actuating). Menurut G.R. Terry pengorganisasian atau penggerakan adalah tindakan mengusahakan hubungan kelakuan yang efektif antara orang-orang, sehingga mereka dapat bekerjasama secara efisien. Menurut Manullang, pengorganisasian adalah suatu proses pembagian pekerjaan, pembatasan tugas-tugas dan tanggung jawab serta wewenang dan penetapan hubungan antar unsur organisasi, sehingga memungkinkan orang dapat bekerja bersama-sama se-efektif mungkin untuk mencapai tujuan. Dengan demikian dapat dipahami bahwa pengorganisasian adalah perbuatan diferensiasi tugastugas dan jalinan hubungan kerja dalam suatu organisasi. ${ }^{10}$

Pengawasan adalah pengamatan dan pengukuran, apakah pelaksanaan dan hasil kerja sudah sesuai dengan perencanaan atau tidak. G.R. Terry menjelaskan bahwa pengawasan sebagai suatu proses penentuan, apa yang harus dicapai yaitu standar, apa yang sedang dilakukan yaitu pelaksanaan, menilai pelaksanaan dan apabila perlu melakukan perbaikan-perbaikan, sehingga pelaksaan sesuai dengan rencana yaitu selaras dengan standar. Definisi GR. Terry menggambarkan bahwa pengawasan memiliki keterkaitan langsung

${ }^{7}$ Ibid., h. 146.

${ }^{8}$ Syahrizal Abbas , Manajemen Perguruan Tinggi ..., h. 100.

${ }^{9}$ Piet Sahertian, Dimensi-dimensi Administrasi Pendidikan di Sekolah (Surabaya: Usaha Nasional, t.th.), h. 315-319. Bandingkan dengan Yusak Burhanuddin yang menyebutkan asas organisasi 1. Harus professional; 2. Pembagian kerja; 3. Pelimpahan wewenang; rentang control; 5. Kesatuan perintah; dan 6. Fleksibel. Lihat, Yusak Burhanuddin, Administrasi Pendidikan (Bandung: Pustaka Setia, 1998), h. 55-56.

${ }^{10}$ Syahrizal Abbas , Manajemen Perguruan Tinggi ..., h. 101. 
dengan perencanaan. Pengawasan baru dapat dilakukan bila telah ada perencanaan sebelumnya. ${ }^{11}$

\section{Manajemen Pendidikan}

Apa yang dimaksud dengan manajemen pendidikan dan apa saja cakupan bahasannya? Dalam Undang-undang RI Nomor 20 Tahun 2003 tentang Sisdiknas, Pasal 1 ayat (1), dinyatakan bahwa "Pendidikan adalah usaha sadar dan terencana untuk mewujudkan suasana belajar dan proses pembelajaran agar peserta didik secara aktif mengembangkan potensi dirinya untuk memiliki kekuatan spiritual keagamaan, pengendalian diri, kepribadian, kecerdasan, akhlak mulia, serta keterampilan yang diperlukan dirinya, masyarakat, bangsa dan negara." 12

Apabila pengertian di atas dipahami dari aspek manajemen yang mencakup rencana, tindakan, dan hasil yang akan dicapai maka ungkapan 'usaha sadar dan terencana' menunjukkan adanya rencana melakukan usaha pendidikan dengan cara yang sadar. Tindakan terencana tentunya diserta dengan proses pembelajaran berupa 'suasana belajar dan proses pembelajaran' yang kondusif dengan satu tujuan utama adalah peningkatan spiritual, intelektual, emosinal, akhlak mulia, keahlian dan kebangsaan.

Ada banyak pengertian manajemen pendidikan yang diajukan para ahli, diantaranya adalah bahwa manajemen pendidikan didefinisikan sebagai seni dan ilmu mengelola sumber daya pendidikan mencapai tujuan pendidikan secara efektif dan efisien. Yang lain mendefinisikan manajemen pendidikan sebagai proses perencanaan, pengorganisasian, pengarahan, dan pengendalian sumber daya pendidikan untuk mencapai tujuan pendidikan secara efektif, efisien, mandiri, dan akuntabel. ${ }^{13}$

Berdasarkan pengertian di atas dapat ditarik kesimpulan bahwa manajeman pendidikan merupakan sebuah upaya secara sadar dan terencana dalam mengelola sumber daya manusia di bidang pendidikan. Apabila pengertian ini yang digunakan maka bahasan tentang praktik manajemen pendidikan kenabian diarahkan pada pelacakan tentang kebijakan-kebijakan Nabi saw. yang mengarah pada pengembangan sumber daya manusia dalam bidang pendidikan melalui empat prinsip dasar manajemen, yakni: planning, organizing, actuating dan controlling. Untuk mendapatkan gambaran yang jelas

\footnotetext{
${ }^{11}$ Ibid. h. 102.

${ }^{12}$ Undang-undang Sistem Pendidikan Nasional

${ }^{13}$ Husaini Usman, Manajemen ..., h. 12.
} 
mengenai inti dari keempat prinsip manajemen tersebut, ringkasan berikut barangkali akan membantu menggambarkannya.

$\begin{array}{lll}\text { Planning } & \longrightarrow & \text { what } \\ \text { Organizing } & \longrightarrow & \text { who } \\ \text { action } \\ \text { Controlling } & \longrightarrow & \text { check }\end{array}$

\section{Hadis-hadis Tentang Manajemen Pendidikan}

Pada dasarnya, hadis tidak menyediakan bentuk operasional dan praktis mengenai manajemen pendidikan. Namun demikian, prinsip-prinsip manajemen sebagaimana yang dijelaskan para ahli tentang manajemen atau administrasi dapat dilacak semangat dan prinsipnya dalam hadis dan praktik Nabi. Hal ini dapat dipahami karena, meski Nabi saw. menyatakan sebagai 'guru' ${ }^{14}$ bagi umat manusia namun beliau tidak diutus untuk membangun dan mendirikan sekolah dengan manajemen seperti yang ada saat ini.

Sebagaimana dijelaskan sebelumnya bahwa ada empat prinsip dasar dalam manajeman atau manajemen pendidikan, yakni: 1. Planning (perencanaan) ; 2. Organizing (mengorganisasi); 3. Actuating (menggerakkan); 4. Controlling (mengawasi). Hadis berikut akan mengemukakan keempat prinsip tersebut, meskipun barangkali: pertama, boleh jadi hadis ini tidak menunjukkan secara eksplisit mengenai makna manajemen pendidikan namun setidaknya memiliki esensi dan semangat yang sama. Kedua, apabila keempat prinsip manajemen pendidikan tersebut merupakan satu kesatuan utuh yang saling terkait maka dalam hadis atau praktik kenabian berikut hanyalah fragmen peristiwa yang terpisah antara satu kasus dengan yang lainnya. Sehingga tidak bisa dikatakan sebagai manajemen pendidikan murni dan utuh dalam dunia pendidikan. Berikut adalah praktik Nabi saw. terkait manajemen pendidikan.

\section{Planning}

Pertanyaan mendasarnya adalah apa yang menjadi planning Nabi saw. berkenaan dengan pendidikan setelah hijrah beliau ke Madinah? Sebelum

${ }^{14}$ Dalam sebuah riwayat dinyatakan bahwa ketika Nabi saw. memasuki masjid beliau menemukan dua kelompok orang di dalamnya. Satu kelompok membaca Alquran dan berdoa sedang kelompok lain belajar dan mengajarkan ilmu. Lalu Rasul bersabda: 'Keduanya baik. Mereka yang membaca Alquran dan berdoa boleh jadi dikabulkan atau ditolak doanya sedang mereka yang belajar dan mengajarkan ilmu maka saya diutus sebagai seorang pengajar. Meski demikian, hadis tersebut dinilai daif oleh al-Albani. Lihat, Abu 'Abdullah Muhammad ibn Yazid al-Qazwini, Sunan Ibn Majah, ditahqiq oleh Muhammad Fu'ad 'Abd al-Baqi, juz 1 (t.p.: Dar Ihya al-Kutub al-'Arabiyyah, t.th.), h. 83. 
datangnya Islam, bangsa Arab dikenal dengan bangsa yang ummi, tidak bisa membaca dan menulis. Data tentang keummian masyarakat Arab dapat diperoleh baik dari Alquran, hadis maupun sejarah. Dalam Q.S. al-Jumu'ah/62: 2, misalnya, Alquran menggambarkan umminya masyarakat Arab dengan:

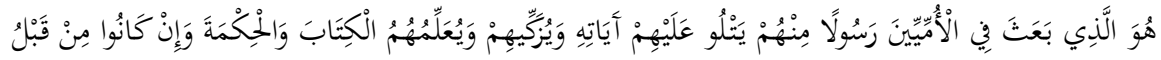

$$
\begin{aligned}
& \text { لَفِي ضَالَالِ مُبِينِ }
\end{aligned}
$$

Artinya:

Dia-lah yang mengutus kepada kaum yang buta huruf seorang Rasul di antara mereka, yang membacakan ayat-ayat-Nya kepada mereka, mensucikan mereka dan mengajarkan mereka Kitab dan Hikmah (As Sunnah). Dan sesungguhnya mereka sebelumnya benar-benar dalam kesesatan yang nyata

Kata 'al-ummi menurut para mufassir berarti tidak dapat membaca dan menulis ${ }^{15}$ atau dapat membaca tetapi tidak bisa menulis. ${ }^{16}$ Makna tersebut dipertegas dengan hadis Nabi yang memaknainya dengan 'tidak bisa menulis dan berhitung. Riwayat al-Bukhari, Muslim, Abu Dawud, al-Nasa’i dan Ahmad, memuat hadis tentang hal itu.

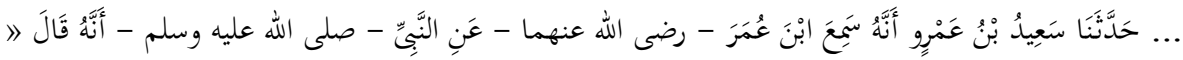

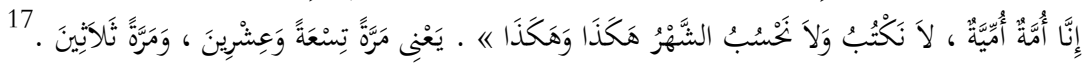

Artinya:

... Diriwayatkan dari Sa'id ibn 'Amr bahwa ia mendengar Ibn 'Umar r.a. dari Nabi saw. bersabda: 'Kami umat yang ummi, tidak dapat menulis dan menghitung. Satu bulan adalah begini, begini, yakni kadang 29 dan terkadang 30 hari.

Data sejarah juga menunjukkan bahwa masyarakat Madinah di mana pemerintah Islam awal dibangun merupakan masyarakat yang buta huruf, yakni tidak dapat membaca atau menulis. Ahmad Amin, misalnya, menyatakan bahwa

\footnotetext{
${ }^{15} \mathrm{Ibn}$ 'Asyur, al-Tabrir wa al-Tanwir, juz 15, al-Maktabah al-Syamilah al-Isdar al-Tsani, h. 74 .

${ }^{16}$ Muhammad ibn Ahmad ibn Abi Bakar al-Qurthubi, al-Jami' li Abkam al-Qur'an, ditahqiq oleh 'Abdullah ibn 'Abd al-Muhsin al-Turki, juz 20 (Beirut: Muassasah al-Risalah, 2006/1427), h. 452. Lihat, Syihab al-Din al-Sayyid Mahmud al-Alusi, Rub al-Ma'ani, juz 28 (Beirut: Dar Ihya al-Turats al-'Arabi, t.th.), h. 93.

${ }^{17}$ Al-Bukhari, op. cit., h. 460.
} 
ketika Islam lahir, kalangan kaum Quraish yang bisa menulis hanya berjumlah 17 orang. ${ }^{18}$ Sedang di kalangan perempuan jumlah lebih sedikit lagi. ${ }^{19}$ Apabila kondisi suku Quraish yang berada di wilayah Hijaz yang terkenal pandai dalam berdagang hanya terdapat 17 orang yang pandai membaca menulis maka wajar apabila kabilah di luar mereka lebih sedikit lagi yang bisa membaca dan menulis. ${ }^{20}$ Meski mayoritas masyarakat Arab berada dalam keadaan ummi, menurut Ibn $\mathrm{H}$ \{ajar, bukan berarti bahwa di antara mereka tidak ada yang bisa sama sekali menulis atau menghitung. Hanya saja jumlah mereka yang bisa menulis sangat sedikit. ${ }^{21}$

Kondisi mayoritas masyarakat yang buta huruf ini tentunya tidak mendukung bagi kemajuan dan perkembangan pemerintahan Islam yang baru ditegakkan di Madinah serta menghambat penyebaran ajaran Islam.

Menurut Ahmad Amin, ada beberapa alasan mengapa membaca dan menulis menjadi penting bagi umat Islam saat itu. Pertama, penyebaran agama Islam memerlukan para pembaca dan penulis. Ketika ayat Alquran ditulis maka mereka yang pandai membaca akan membacakan kepada yang tidak bisa membaca. Kedua, Islam menyebarkan ajaran-ajaran yang ada pada masa Nabi sebelumnya kepada masyarakat Arab. Selain itu, Islam juga menjelaskan hukum tentang nikah, talak, aturan hidup bermasyarakat dan ekonomi. ${ }^{22}$ Ketiga, menurut penulis, pemerintahan Islam yang baru perlu melakukan kontak dengan para penguasa di luar Arab baik dalam kerangka mengenalkan Islam maupun menginformasikan hadirnya pemerintahan baru di Arab sehingga memerlukan sekretaris yang handal untuk menulis, membaca atau menjawab surat-surat yang dikirimkan para penguasa ke negara Islam. Keempat, Alquran yang diturunkan kepada Nabi saw. tidak hanya dihafal tetapi juga beliau ingin

${ }^{18}$ Mereka adalah 'Umar ibn al-Khaththab, 'Ali ibn Abi Thalib, 'Utsman ibn 'Affan, Abu 'Ubaidah ibn al-Jarrah, Thalhah, Yazid ibn Abi Sufyan, Abu Huzaifah ibn 'Utbah, Hatib ibn 'Amar, Abu Salamah ibn 'Abd al-Asad al-Makhzumi, Aban ibn Sa'id, Khalid ibn Sa'id, 'Abdullah ibn Sa'id, Huwaitib ibn 'Abd al-'Uzza, Abu Sufyan ibn Harb, Mu'awiyah ibn Abu Sufyan, Juhaim ibn al-Shalat dan al-'Ala ibn al-Hadrami. Lihat, Ahmad Amin, Fajr al-Islam, h. 140 .

${ }^{19} \mathrm{Di}$ antara perempuan yang pandai menulis atau membaca adalah Hafshah dan Ummu Kultsum, al-Syifa binti 'Abdullah al-'Adawiyah, sedang 'Aisyah hanya bisa membaca dan tidak bisa menulis, demikian juga Ummu Salamah. Lihat, Ibid.

${ }^{20} \mathrm{Ahmad}$ Amin, Fajr al-Islam (Beirut: Dar al-Kitab al-'Arabi, t.th.), h. 140.

${ }^{21}$ Ahmad ibn 'Ali ibn Hajar al-'Asqalani, Fath al-Bary, ditahqiq oleh 'Abd al-Qadir Syaibah al-Hamd, juz 4 (Riyadh: 'Abd al-Aziz Ali Sa'ud, t.th.), h. 151.

${ }^{22}$ Ahmad Amin, Fajr al-Islam ..., h. 141. 
agar ayat tersebut ditulis oleh para sahabat khusus penulis Alquran. ${ }^{23}$ Saat pertama datang ke Madinah, orang pertama yang diminta Rasul menulis adalah Ubay ibn Ka'ab al-Anshari dan jika ia tidak datang beliau akan memanggil Zayd ibn Tsabit al-Anshari. ${ }^{24}$

Dengan kondisi ini, menurut penulis, planning utama dan mendesak yang akan dilakukan Nabi saw. berkenaan dengan pemerintah baru Islam adalah terkait persoalan pendidikan terutama pengentasan buta huruf di kalangan sahabat. Ada beberapa langkah yang diambil Nabi saw. berkenaan dengan hal tersebut. Pertama, menjadikan pengajaran membaca dan menulis sebagai bagian bentuk tebusan bagi tawanan perang terutama tawanan perang Badar. ${ }^{25}$ Ibn Sa'ad, misalnya, memuat peristiwa tersebut dalam riwayat berikut:

$$
\begin{aligned}
& \text { أخبرنا الفضل بن دكين، أخبرنا إسرائيل عن جابر عن عامر قال: أسر رسول الله، صلى الله عليه وسلم، يوم }
\end{aligned}
$$

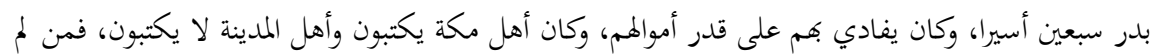

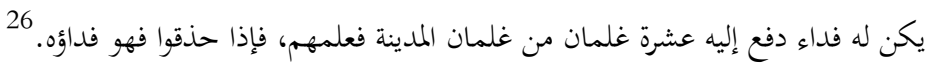

Artinya:

... Dari 'Amir berkata: Rasulullah saw. menawan 70 orang tawanan perang Badar dan mereka dapat menebus berdasarkan harta yang dimiliki. Selain itu, orang-orang Makkah pandai menulis sedang orang Madinah tidak pandai. Maka siapa yang tidak dapat menebus dirinya

${ }^{23}$ Di antara sahabat yang diperintahkan untuk menulis Alquran adalah Abu Bakar (Muhajirin), 'Umar ibn al-Khaththab (Muhajirin), 'Utsman ibn 'Affan (Muhajirin), 'Ali ibn Abi Thalib (Muhajirin), Mu'awiyah ibn Abu Sufyan (Muhajirin), Aban ibn Sa'id (Muhajirin), Khalid ibn Sa'id (Muhajirin), Ubay ibn Ka'ab (Ansar), Zayd ibn Tsabit (Ansar), Tsabit ibn Qays (Ansar) dan lainnya. Lihat, Muhammad 'Abd al-Azhim al-Zarqani, Manabil al-Irfan fi 'Ulum alQur'an, ditahqiq oleh Fawwaz Ahmad Zamrali, juz 1 (Beirut: Dar al-Kitab al-'Arabi, 1995/1415), h. 202.

${ }^{24}$ Ahmad Amin, Fajr al-Islam...

${ }^{25}$ Ketika Nabi saw. bermusyarawah dengan beberapa sahabat terkait perlakuan atas tawanan perang Badar, Abu Bakar mengusulkan agar mereka membayar fidyah sesuai dengan kemampuan mereka dari 4000 sampai 1000 auqiyah (diriwayat lain dirham) sedang 'Umar mengusulkan agar mereka dibunuh. Nabi kemudian mengikuti saran Abu Bakar. Keputusan Nabi saw. tersebut keliru karena kemudian turun ayat yang menegur beliau. Lihat, Muslim, op. cit., h. 969. Lihat, Shafiy al-Din al-Mubarakfuri, al-Rabiq al-Makbtum (t.tp.: Maktabah Nur alIslam, t.th.), h. 180.

${ }^{26}$ Muhammad ibn Sa'ad Mani' al-Zuhri, Kitab al-Thabaqat al-Kubra, ditahqiq oleh 'Ali Muhammad 'Umar, juz 2 (Kairo: Maktabah al-Khanzi, 2001/1421), h. 20. Lihat, Shafy al-Din, al-Rabiq al-Makbtum ..., h. 180. 
dengan uang dapat menggantinya dengan mengajarkan 10 anak Madinah hingga mereka pandai..

Kedua, Nabi saw. memerintahkan sahabat tertentu, seperti Zayd ibn Tsabit untuk mempelajari bahasa Ibrani/Yahudi dan bahasa Suryani. Penjelasan lebih lanjut mengenai hal ini akan diuraikan pada bahasan berikut.

Perintah dan doroangan Nabi saw. untuk belajar membaca dan menulis pada akhirnya menghasilkan banyak sahabat yang pandai membaca dan menulis. Pada perang Yamamah tahun $12 \mathrm{H}$, atau dua tahun setelah wafatnya Rasulullah, dimana terjadi peperangan melawan mereka yang murtad pengikut Musailamah al-Kazzab, misalnya, dinyatakan bahwa sebanyak 70 orang penghafal dan pembaca (al-qurra) Alquran terbunuh bahkan sebagian menyebutkan berjumlah 500 orang. ${ }^{27}$ Kata 'al-qurra' tersebut dipahami sebagai mereka yang mampu membaca.

Meski penulis belum menemukan data berapa jumlah sahabat yang mampu membaca dan menulis di akhir masa kenabian sebagai bagian dari gerakan pementasan buta huruf, informasi mereka yang terbunuh pada perang Yamamah di atas setidaknya menunjukkan adanya peningkatan jumlah mereka yang mampu membaca dan menulis di kalangan sahabat. Pengajaran membaca dan menulis menjadi pondasi bagi perkembangan pemerintahan Islam dan kemajuan peradaban Muslim selanjutnya sehingga tepat apabila Nabi saw. menjadikannya salah satu planning utama saat awal membangun pemerintahan Islam. Dengan keberhasilan program tersebut maka dapat dinyatakan bahwa Nabi saw. menjadi pelopor gerakan pemberantasan buta huruf pertama dalam sejarah peradaban dunia. Dan yang terpenting adalah bahwa dalam kerangka menjalankan dan mendukung roda pemerintahan Islam, Nabi saw. memiliki planning yang jelas dalam bidang pendidikan.

\section{Organizing (mengorganisasi)}

Mengorganisasi dipahami oleh para ahli manajemen sebagai menempatkan orang tertentu pada posisi dan jabatan yang tepat sehingga tujuan dan target organisasi dapat tercapai. Dalam praktiknya, Nabi sering melakukan prinsip tersebut. Dalam dunia pendidikan, misalnya, beliau memerintahkan Zaid ibn Tsabit untuk belajar bahasa Ibrani, bahasanya umat Yahudi, dan bahasa Suryani dan tidak memerintahkan sahabat lainnya. Padahal pada saat itu sudah ada beberapa orang sahabat yang pandai membaca dan menulis yang masuk dalam jajaran para penulis wahyu. Namun demikian, Nabi saw. hanya memilih Zayd ibn Tsabit dan tidak yang lain. Dalam keputusannya

${ }^{27} \mathrm{Al}$-Zarqani, Manabil al-Trfan ..., h. 205. 
tersebut, Nabi saw. tidak keliru karena Zayd mampu mempelajari bahasa Ibrani dan Suryani dalam 7 hari dan sebagian riwayat setengah bulan. Riwayat dan hadis berikut menunjukkan hal itu.

$$
\begin{aligned}
& \text { أخبرنا يهيى بن عيسى الرملي، أخبرنا الأعمش عن ثابت بن عبيد الله عن زيد بن ثابت قال: قال لي رسول }
\end{aligned}
$$

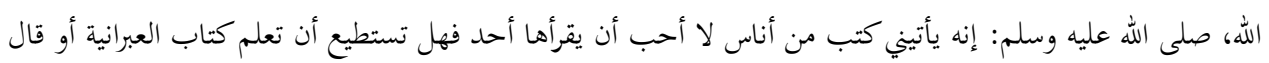

$$
\begin{aligned}
& \text { السريانية؟ فقلت: نعم! قال: فتعلمتها في سبع عشرة ليلة. } 28
\end{aligned}
$$

Artinya:

... Dari Zayd ibn Tsabit berkata: Rasulullah saw. berkata kepadaku: 'Telah datang kepadaku surat dari masyarakat luar dan aku tidak suka seorang pun membacanya maka bisakah kamu mempelajari bahasa Ibrani atau Suryani (Siria)? Zayd menjawab: 'Ya'. Ia lalu mengatakan: 'Saya mampu mempelajarinya dalam 7 malam.

Dalam riwayat al-Tirmizi, misalnya, dinyatakan:

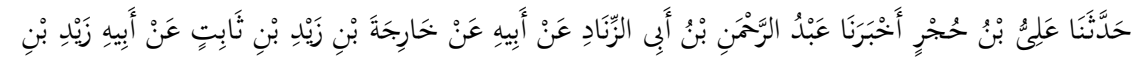

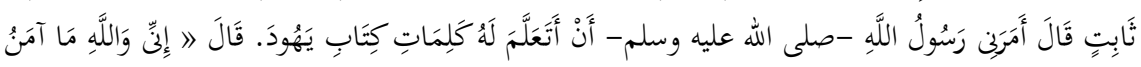

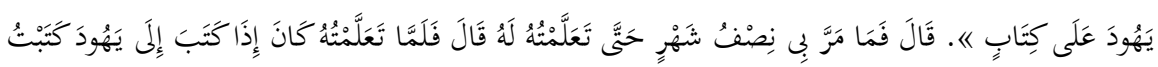

$$
\begin{aligned}
& 2929 .
\end{aligned}
$$

Artinya:

... Dari Zayd ibn Tsabit berkata: Rasulullah saw. memerintahkanku untuk belajar bahasa Yahudi. Beliau bersabda: 'Sungguh, demi Allah, saya tidak percaya kepada orang Yahudi untuk membacakan surat (yang dikirim dalam bahasa mereka atau Ibrani). Zayd berkata: 'Tidak lebih dari setengah bulan saya telah menguasainya sehingga apabila beliau berkirim surat kepada orang Yahudi maka saya lah yang menuliskannya dan apabila mereka mengirim surat untuk Nabi saw. maka sayalah yang membacakannya untuk beliau.

Dalam hal ini, Rasulullah tidak hanya memerintahkan sahabatnya untuk mempelajari ilmu syari'ah yang diambil dari Alquran dan hadis namun memerintahkan juga untuk mengkaji ilmu yang mendatangkan manfaat bagi kaum Muslim secara umum. Selain itu, perintah Nabi kepada Zayd ini disesuaikan dengan kemampuan dan kecakapan Zayd. Pada waktu pertama kali

\footnotetext{
${ }^{28} \mathrm{Ibn}$ Sa'ad, op. cit., juz 2, h. 309.

${ }^{29}$ Muhammad ibn 'Isa ibn Surah al-Tirmizi, Sunan al-Tirmizi, dita'liq oleh Muhammad Nashr al-Din al-Albani (Riyad\}: Maktabah al-Ma'arif, t.th.), h. 611.
} 
Nabi sampai di Madinah beliau mendengar Zayd ibn Tsabit hafal lebih dari sepuluh ayat padahal ia masih kecil dan Nabi kagum dengan kemampuan Zayd tersebut sehingga beliau memerintahkannya untuk mempelajari bahasa Ibrani. ${ }^{30}$

Fakta ini menunjukkan bahwa Nabi saw. mengetahui potensi yang dimiliki masing-masing sahabat dan menempatkan mereka sesuai dengan bakat, potensi dan kemampuannya. Penempatan seseorang berdasarkan kemampuannya ini menunjukkan bahwa Nabi saw. adalah seorang manajer dan organisatoris ulung yang tidak hanya menempatkan sahabat pada tempat yang tepat namun apa yang menjadi tujuan organisasi dapat tercapai dengan baik.

Ada kasus lain yang menunjukkan bahwa Nabi memahami betul potensi sahabat beliau dalam kepemimpinan dan menempatkannya pada tempat yang tepat demi tercapainya apa yang menjadi tujuan organisasi. Dalam kasus Abu Dzar yang meminta jabatan kepada Nabi namun beliau tidak memberikannya dengan alasan bahwa Abu Dzar tidak berkompeten dalam hal itu. Hadis tersebut berbunyi:

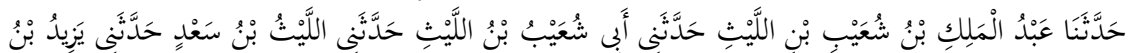

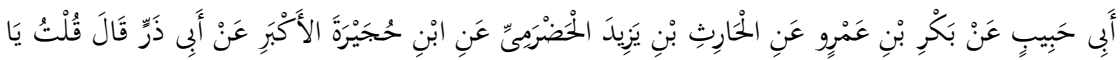

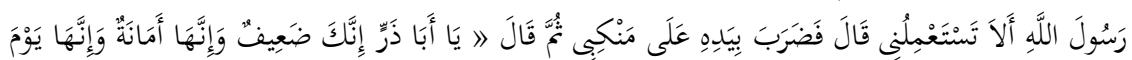

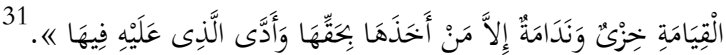

Artinya:

... Dari Abu Dzar ia berkata, saya berkata: 'Wahai Rasulullah mengapa engkau tidak angkat aku sebagai pejabatmu. Lalu Nabi menepuk pundaknya seraya bersabda: 'Wahai Abu Dzar, kamu orangnya lemah sedang jabatan adalah amanah yang menjadi kehinaan dan penyesalan di hari kiamat kecuali bagi mereka yang mendudukinya secara benar (tepat) dan menjalankannya dengan benar.

Menurut al-Nawawi, hadis ini menunjukkan bahwa kehinaan dan penyesalan akan menimpa mereka yang tidak memiliki kompetensi dalam memimpin atau mereka yang berkompeten namun tidak dapat berlaku adil maka pada hari kiamat dihinakan dan menyesalinya. Namun bagi mereka yang mampu mengemban kepemimpinan dan berlaku adil dalam menjalankannya maka ini merupakan kemuliaan yang besar sebagaimana yang termuat dalam

\footnotetext{
${ }^{30}$ Sa'id Isma'il 'Ali, al-Sunnah al-Nabawiyyah: Ru'yah Tarbawiyyah (Kairo: Dar al-Fikr al'Arabi, 2002/1423), h. 243.

${ }^{31}$ Muslim ibn al-Hajjaj, op. cit., h. 1015.
} 
hadis bahwa mereka termasuk tujuh orang yang mendapat perlindungan di hari kiamat. ${ }^{32}$

Bagaimana sesungguhnya profil Abu Dzar sehingga Nabi saw. menolaknya menjadi pejabat pemerintah? Dalam hadis dan kitab-kitab sejarah disebutkan bahwa Abu Dzar dikenal sebagai seorang pemberani dalam mengungkapkan dan mengatakan kebenaran meskipun nyawa menjadi taruhannya. Keberanian Abu Dzar tergambar dalam banyak riwayat, berikut:

Pertama, ia termasuk orang yang pertama masuk Islam dan menyatakan keislamannya secara terbuka di depan Ka'bah sehingga dipukul banyak orang sampai jatuh dan diselamatkan 'Abbas. Perbuatan tersebut ia ulangi kembali esok harinya dan mendapat perlakuan yang sama. ${ }^{33}$

Kedua, ia tetap memberi fatwa meski telah dilarang oleh penguasa. Diriwayatkan, ketika Abu Dzar ditanya oleh seseorang: 'Bukankah Amir alMu'minin melarangmu untuk memberi fatwa? Abu Dzar lantas menjawab: 'Demi Allah, sekiranya kalian meletakkan pedang di tenggorokanku agar aku tidak mengucapkan apa yang ku dengar dari Rasulullah niscaya ku akan mengatakan sebelum pedang itu menembus leherku'. ${ }^{34}$

Ketiga, ia diasingkan oleh Khalifah 'Utsman ibn 'Affan ke daerah Rabadzah disebabkan berselisih dengan Mu'awiyah mengenai ayat 'wa alladzina yaknizuna al-dzahaba (al-Bara'ah ayat 34). ${ }^{35}$

Berbagai rekam jejak peristiwa tersebut menunjukkan bahwa Abu Dzar merupakan seorang sahabat pemberani dan tidak merasa takut meski berseberangan pendapat dengan pemimpin dan siap menanggung resiko yang besar atas sikapnya itu. Sikap ini menunjukkan bukti akan keberanian dan keteguhan Abu Dzar dalam mengemukakan pendapat meski menanggung resiko besar. Keberanian ini tentunya merupakan modal penting bagi seseorang

${ }^{32} \mathrm{Al}-\mathrm{Imam}$ al-Nawawi, Shabih Muslim bi Syarh al-Nawawi, juz 12 (Mesir: al-Mathba'ah al-Mishriyyah, 1930/1349), h. 210. Lihat, 'Iyadh ibn Musa ibn 'Tyadh al-Yahshabi, Ikmal alMu'lim bi Fawaid Muslim, ditahqiq oleh Yahya Isma’il, juz 6 (Mesir: Dar al-Wafa, 1998/1419), h. 225.

${ }^{33}$ Ahmad ibn 'Ali al-'Asqalani, al-Ishabah fi Tamyiz al-Shababah, ditahqiq oleh Thaha Muhammad al-Zaini, juz 11 (Kairo: Maktabah Ibn Taimiyah, 1993/1412), h. 120.

${ }^{34} \mathrm{Ibn}$ Sa'ad, op. cit., juz 2, h. 305.

${ }^{35}$ Ali ibn Ahmad al-Wahidi al-Naisaburi, Asbab al-Nuzul, ditakhrij oleh 'Isham ibn 'Abd al-Muhsin al-Humaidan (Saudi: Dar al-Ishlah, 1992/1412), h. 243. Lihat, Al-Bukhari, op. cit., h. 341. 
untuk menjadi pemimpin. ${ }^{36}$ Namun demikian, Nabi tetap tidak memberinya jabatan tertentu dalam pemerintahan.

Menurut al-Qurthubi, sebagaimana dikutip Ibn al-Allan dalam Dalil alFalibin, kelemahan Abu Dzar terletak pada kepribadiannya yang cenderung kepada hidup asketik (zuhud) dan kurang memperhatikan urusan duniawi. Atas dasar ini, Rasulullah saw. menasehatinya agar tidak meminta jabatan tersebut. ${ }^{37}$ Dengan kecenderungan asketis tersebut barangkali Nabi saw. menilai jabatan pemerintahan tidak coock untuk Abu Dzar sehingga beliau menolak memberinya jabatan meskipun ia seorang yang taat dan kuat keislamannya.

Beragam kebijakan Nabi saw. tersebut menunjukkan bahwa beliau adalah seorang organisatoris ulung yang memahami seluruh potensi, bakat dan kemampuan sahabatnya sehingga menempatkan mereka pada posisi dan kedudukan yang tepat demi tercapainya tujuan organisasi. Sikap Nabi saw. tersebut terangkum dalam satu ucapan beliau berikut:

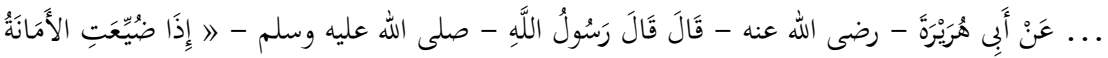

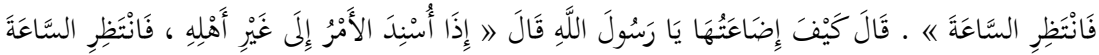

$$
\begin{aligned}
& 38
\end{aligned}
$$

Artinya:

... Dari Abu Hurairah r.a. berkata, Rasulullah saw. bersabda: 'Apabila sifat amanah sudah hilang maka tunggulah kiamat akan datang' kemudian Rasul ditanya: 'Bagaimana hilangnya?' Rasul saw. menjawab: 'Apabila satu urusan disandarkan kepada yang bukan ahlinya maka tunggulah kiamat akan datang (kehancurannya).

Kata 'al-amr' pada hadis di atas mencakup semua hal terkait agama, seperti, khilafah, kepemimpinan, hakim dan majlis fatwa dan lainnya. Dengan mengangkat orang yang tidak ahli agama dan tidak amanah atau mengangkat mereka yang membantu berbuat zalim dan kejahatan. Dengan demikian,

\footnotetext{
${ }^{36}$ Menurut al-Mawardi, syarat menjadi pemimpin ada tujuh macam, yakni: 1. Adil; 2.
} Ilmu yang memungkinkannya dapat berijtihad dalam bidang hukum; 3. Sehat panca indera; 4. Sehat fisik dan jasmani; 5. Berwawasan dan dapat memimpin masyarat serta mengatur kemaslahatan mereka; 6. Pemberani sehingga dapat melindungi rakyat dan melawan musuh; 7. Bernasabkan Quraish. Lihat, 'Ali ibn Muhammad ibn Habib al-Mawardi, al-Abkam alSulthaniyyah wa al-Wilayat al-Diniyyah, ditahqiq oleh Ahmad Mubarak al-Bagdadi (Kuwait: Maktabah Dar Ibn Qutaibah, 1998/1409), h. 5.

${ }^{37}$ Sebagaimana dikutip, Ahmad Sutarmadi, Meneropong Jejak Rasul: Revitalisasi Hadis (Cet. I; Jakarta: CMB Press, 2008), h. 241.

${ }^{38} \mathrm{Al}-\mathrm{Bukhari}$, op. cit., h. 1615. 
pemimpin telah menghilangkan sifat amanah yang telah Allah wajibkan sehingga orang khianat dipercaya dan orang yang jujur berkhianat. Ini terjadi apabila orang bodoh menguasai dan orang benar tidak mampu melaksanakan satu urusan. ${ }^{39}$ Hadis di atas ingin menyatakan bahwa segala urusan harus diserahkan kepada ahlinya.

Berbagai kebijakan dan sabda Nabi saw. di atas menunjukkan beliau memiliki kemampuan memimpin dan mengorganisasi serta mengelola potensi sahabat dengan baik. Berdasarkan potensi tersebut beliau menempatkan sahabatnya pada posisi yang sesuai dengan bakatnya sehingga tujuan organisasi dapat tercapai.

\section{Actuating (menggerakkan)}

Dalam manajemen, actuating dipahami sebagai kemampuan seorang pemimpin menggerakkan bawahan, pengikut atau anggotanya untuk berbuat dan melakukan sesuatu untuk mencapai apa yang menjadi tujuan organisasi. Kemampuan ini mendorong para pengikut bergerak dan berbuat sesuai dengan keinginan pemimpin dan tujuan organisasi. Dalam dunia pendidikan, kemampuan Nabi saw. dalam menggerakkan sahabatnya tergambar dengan jelas ketika sekelompok perempuan meminta Nabi saw. untuk mengajarkan kepada mereka ilmu pengetahuan. Hadis berikut mengungkapkan hal tersebut.

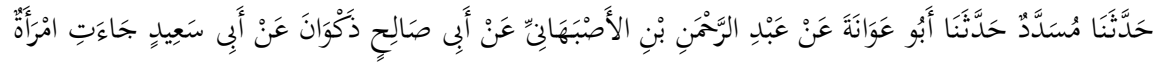

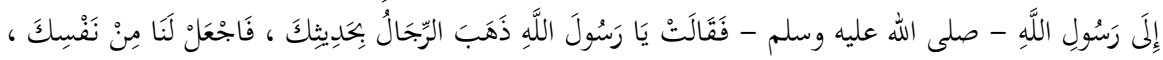

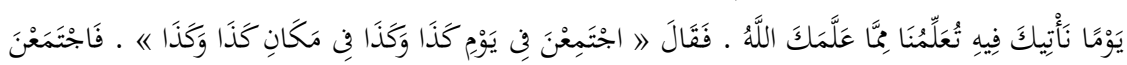

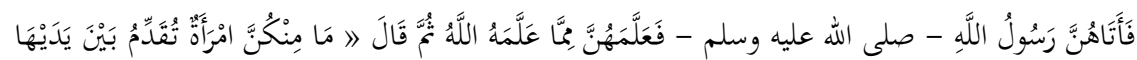

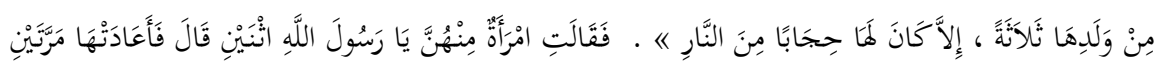

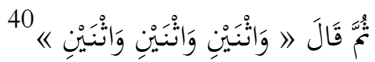

Artinya:

... Dari Abu Sa’id al-Khudri menceritakan bahwa perempuan datang kepada Rasulullah saw. dan berkata wahai Rasulullah, kaum lelaki telah datang untuk mendapatkan hadis darimu, maka tentukan olehmu bagi

${ }^{39}$ Badr al-Din Abu Muhammad Mahmud ibn Ahmad al-'Aini, 'Umdah al-Qari Syarh Shabih al-Bukhari, ditashhih oleh 'Abdullah Mahmud Muhammad 'Umar, juz 2 (Beirut: Dar alKutub al-'Ilmiyyah, 2001/1421), h. 10. Lihat, Ahmad ibn 'Ali ibn Hajar al-'Asqalani, Fath alBary, ditahqiq oleh 'Abd al-Qadir Syaibah Hamd, juz 11 (Saudi: al-Amir Sulthan ibn 'Abd al'Aziz, t.th.), h. 341.

${ }^{40}$ Al-Bukhari, op. cit., h. 1806. 
kami satu waktu yang kami datang dan engkau mengajarkan apa yang telah diajarkan Allah. Nabi saw. lalu bersabda: 'Berkumpullah kalian pada hari A dan di tempat B. Mereka lalu berkumpul dan mendatanginya untuk mengajarkan ajaran ilahiah kepada mereka. Beliau bersabda: 'Siapa saja dari kalian para wanita yang ditinggal mati oleh tiga orang anaknya maka anak tersebut dapat menjadi penghalang baginya dari api neraka. Seorang perempuan bertanya: 'Wahai Rasulullah, bagaimana jika dua orang. Perempuan tersebut mengulang pertanyaannya sebanyak dua kali. Nabi saw. menjawab: 'Ya, meski dua orang'.

Dalam menjelaskan hadis tersebut, para pensyarah hanya melihat pada aspek ajaran agama dengan menyatakan perlunya mengharapkan ridha Allah ketika ditinggal mati oleh anaknya. ${ }^{41}$ Sebagian lainnya menjelaskan bahwa sabar dan mengharap ridha Allah menjadi syarat utama bagi pemberian syafaat terhadap orang tua yang ditinggal mati anaknya. ${ }^{42}$

Dalam kaitannya dengan pendidikan, ada beberapa hal yang dapat dicatat pada hadis di atas dan kurang mendapat perhatian dari para ulama hadis terkait kedudukan perempuan dalam menuntut ilmu. Pertama, kaum perempuan menuntut hak yang sama dengan laki-laki dalam bidang pendidikan. Kedua, Rasulullah memberikan apresiasi yang besar terhadap keinginan perempuan dengan memberikan waktu beliau untuk mengajarkan ajaran agama kepada perempuan. Ketiga, materi yang disampaikan merupakan sesuatu yang sangat dekat dengan kepentingan perempuan yakni terkait dengan anak.

Apa yang mendorong para perempuan bersemangat untuk menuntut ilmu sebagaimana kaum laki-laki? Padahal masa jahiliah belum lama berlalu dimana laki-laki memegang semua peran dalam sebuah suku sedang perempuan tidak mendapat penghargaan, ditinggalkan dan diabaikan hak-hak hidupnya. Jika bukan karena dorongan, semangat dan peluang yang diberikan Rasul kepada mereka tentunya mereka tidak akan menuntut hak yang sama dengan para laki-laki dalam menuntut ilmu. Hasil dari pendidikan Rasul ini adalah lahirnya perempuan yang terlibat aktif dalam berbagai bidang kehidupan masyarakat Muslim. 'Aisyah, isteri Nabi saw. sendiri dikenal sebagai ahli hadis dan hukum Islam. Pada generasi yang berbeda, juga lahir ahli hukum di kalangan perempuan seperti Nafisah dan Syuhdah. ${ }^{43}$ Bukan hanya perempuan

${ }^{41}$ 'Iyadh ibn Musa, op. cit., juz 8, h. 115.

${ }^{42}$ Ibn Hajar al-'Asqalani, op. cit., juz 3, h. 143.

${ }^{43}$ Haifaa A. Jawad, Otentisitas Hak-bak Perempuan: Perspektif Islam Atas Kesetaraan Jender, terjemah dari The Right of Women in Islam: An Authentic Approach (Yogyakarta: Fajar 
yang belajar dari mereka tetapi juga terdapat sekelompok laki-laki yang menimba ilmu dari mereka. Inilah buah manis dari pendidikan yang ditanamkan Nabi saw. kepada kaum perempuan.

\section{Controlling}

Mengontrol dengan cara menguji untuk mengetahui sejauh mana penguasaan anak didik terhadap materi yang disampaikan guru merupakan bagian penting dalam pengajaran. Selain itu, anak didik mempertanyakan apa yang belum dipahaminya dari materi yang diajarkan guru termasuk bagian pengajaran yang juga tidak kalah pentingnya. Dalam hal ini terdapat riwayat dimana 'Aisyah mempertanyakan kepada Nabi saw. apa yang tidak ia pahami dari perkataan beliau. Hadis tersebut berbunyi:

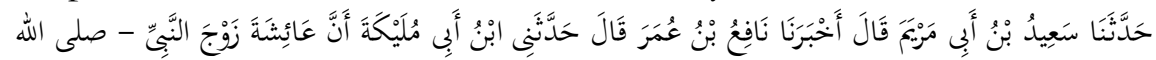

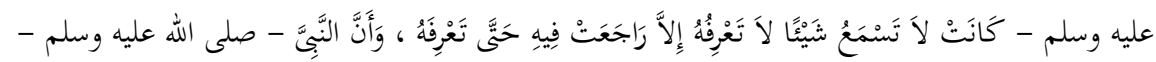

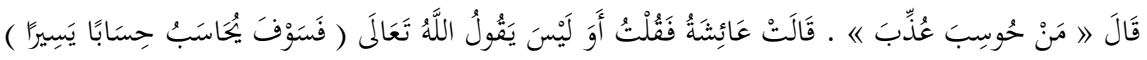

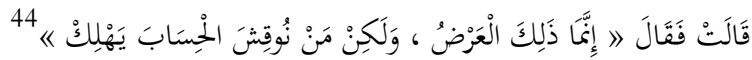

Artinya:

... Meriwayatkan kepadaku Ibn Abi Mulaikah bahwa 'Aisyah isteri Nabi saw. jika mendengar sesuatu yang ia tidak pahami maka selalu ia tanyakan hingga paham. Ketika Rasulullah mengatakan: 'Siapa yang dihisab ia pasti akan disiksa'. 'Aisyah berkata: 'Bukankan Allah swt. berfirman: 'Maka Ia akan menghitung dengan hitungan yang mudah'. Lalu Nabi saw. menjawab: 'Yang dimaksud adalah pemaparan (amal selama di dunia) namun siapa yang hitungan amalnya diperdebatkan (lebih sedikit amal baiknya) niscaya ia akan binasa.

Menurut Abu Lubabah, selain guru menjelaskan secara berulang materi yang disampaikan kepada anak didik, hal terpenting dalam pembelajaran juga adalah meminta mereka untuk menyebutkan ulang dan menguji sejauh mana hafalan dan penguasaan mereka terhadap materi tersebut. Salah satu cara yang dapat digunakan adalah meminta mereka untuk mengajar atau unjuk kerja dan dapat juga dengan menguji materi yang diajarkan. ${ }^{45}$

Pustaka Baru, 2002), h. 72. Lihat, Syed Ameer Ali, The Spirit of Islam, penerj. Margono dan Kamilah (Yogyakarta: Navila, 2008), h. 293.

${ }^{44}$ Al-Bukhari, op. cit., h. 39.

${ }^{45} \mathrm{Abu}$ Lubabah Husain, al-Tarbiyah fi al-Sunnab al-Nabawiyah (Riyadh: Dar al-Liwa, t.th.), h. 71 . 
Dalam banyak kesempatan, tidak jarang Nabi bertanya kepada sahabatnya tentang suatu hal yang ingin beliau jelaskan. Pertanyaan tersebut dimaksudkan untuk mengetahui sejauhmana pengetahuan sahabat mengenai materi yang akan beliau sampaikan. Satu waktu Nabi saw., misalnya, bertanya tentang siapa orang yang bangkrut dalam kehidupannya. Pertanyaan tersebut beliau lontarkan kepada para sahabat untuk menunggu jawaban yang akan diberikan. Dalam beberapa riwayat, pertanyaan tersebut kadang mereka jawab namun sering juga tidak. Di antara pertanyaan Nabi saw. tersebut adalah siapa yang dimaksud dengan orang 'muflis'. Hadis berikut menjelaskan peristiwa pengujian Nabi saw. kepada sahabatnya.

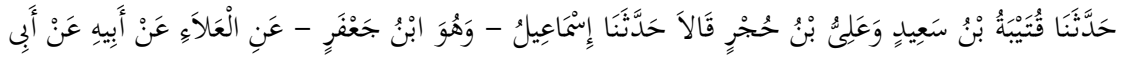

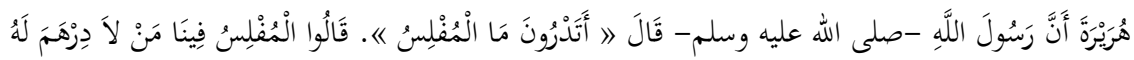

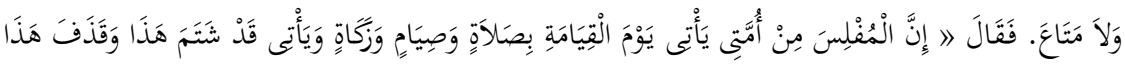

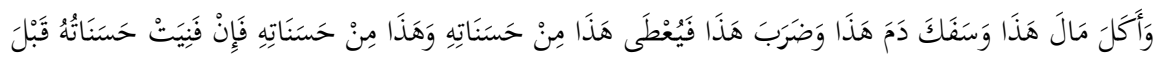

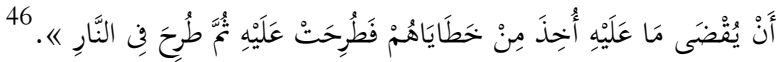

Artinya:

... Dari Abu Hurairah bahwa Rasulullah saw. bersabda: 'Tahukan kalian apa itu al-muflis?' Sahabat menjawab: 'Orang yang muflis di antara kami adalah mereka yang tidak memiliki uang (dirham) dan makanan. Beliau menjawab: 'Orang yang muflis di kalangan umatku adalah mereka yang ketika hari kiamat didatangkan salatnya, puasanya, zakatnya dan kemudian didatangkan juga perbuatannya yang mencaci $\mathrm{A}$, menuduh $\mathrm{B}$, memakan harta $\mathrm{C}$, menumpahkan darah $\mathrm{D}$, dan memukul $\mathrm{E}$, lantas semua kesalahan tersebut dibalas dengan kebaikan yang ada padanya dan jika seluruh kebaikannya telah habis sebelum terlunasi semua kejahatannya maka kesalahan orang lain itu akan diambil dan ditimpakan padanya kemudian ia dilemparkan ke dalam api nerakan.

Menurut 'Iyadh, hakikat khusus muflis adalah orang yang memiliki kebaikan namun kebaikannya diberikan kepada orang lain seperti orang yang berhutang dan hartanya diambil untuk membayar hutang-hutangnya. Hal ini karena orang beranggapan bahwa yang bangkrut adalah mereka yang sedikit dan tidak memiliki harta. Padahal, itu bukanlah hakikat muflis karena yang

46Muslim ibn al-Hajjaj, op. cit., h. 1394. 
demikian itu dapat hilang dan terputus ketika seseorang meninggal dan boleh jadi dapat hilang setelah berlalunya waktu dalam hidupnya selanjutnya. ${ }^{47}$

Dalam menjelaskan hadis, para pensyarah tidak menghubungkannya dengan konsep dan pemikiran pendidikan meski pada hadis tersebut mengandung makna pendidikan. Hal ini disebabkan karena alam pemikiran dan masyarakat mereka saat itu lebih terfokus pada unsur dan nilai-nilai keagamaan. Jika dilihat dari sudut pandang pendidikan terutama aspek evaluasi, hadis tersebut menunjukkan bahwa Nabi terkadang menguji pemahaman sahabat mengenai sesuatu untuk mengetahui sejauh mana pandangan mereka tentang hal tersebut. Apabila apa yang mereka pahami ternyata tidak sesuai dengan apa yang dimaksud oleh Nabi saw. maka beliau akan menjelaskannya secara jelas sehingga mereka pun dapat memahaminya.

\section{Penutup}

Apa yang dilakukan Nabi saw. berkenaan dengan pendidikan pada dasarnya mengandung prinsip-prinsip manajemen pendidikan modern. Pendidikan tersebut diawali dengan program pengentasan buta huruf di kalangan sahabat dengan menjadikan pengajaran membaca dan menulis sebagai satu bentuk penebus bagi tawanan perang Badar. Kebijakan Nabi saw. tersebut juga diikuti dengan perintah beliau kepada Zayd ibn Tsabit untuk mempelajari bahasa Ibrani dan Suryani yang merupakan bahasa di luar masyarakat Arab. Penunjukkan Zayd ini menandakan bahwa Nabi saw. melakukan pengaturan atau organizing atas sahabat beliau yang disesuaikan dengan potensi, bakat dan kemampuan masing-masing orang. Pengorganisasian ini ditegaskan juga oleh Nabi saw. melalui sabda beliau bahwa segala urusan yang tidak diserahkan kepada mereka yang berkompeten maka akan mendatangkan kehancuran. Tindakan Nabi saw. dalam dunia pendidikan ini mampu menggerakkan seluruh unsur dalam masyarakat Muslim awal untuk semangat dalam menuntut ilmu sehingga mendorong para perempuan untuk meminta kesamaan hak dalam pengajaran kepada Nabi saw. sebagaimana yang didapat kaum lelaki. Semangat untuk bergerak dan berbuat dalam dunia pendidikan ini dapat dikategorikan sebagai aksi dan aktualisasi sahabat dalam bidang pengajaran. Dalam praktik pengajaran, Nabi saw. tidak jarang menanyakan kepada sahabatnya berkenaan dengan materi apa yang akan beliau sampaikan untuk mengetahui sejauh mana pengetahuan sahabat terhadap materi tersebut. Selain bertanya, tidak jarang juga Nabi saw. ditanya para sahabat tentang materi yang beliau sampaikan

${ }^{47}$ Iyadh ibn Musa, op. cit., juz 8, h. 50. Lihat, al-Nawawi, op. cit., juz 16, h. 136. 
apabila mereka belum memahaminya. Bertanya dan ditanya dalam aktivitas pendidikan dapat dikatakan sebagai proses pengujian atau control atau kualitas pembelajaran.

\section{Daftar Pustaka}

Abadi, Abu 'Abd al-Rahman Syaraf al-Haq al-'Azim. 'Aun al-Ma'bud 'ala Syarb Sunan Abi Dawnd, Beirut, Dar Ibn Hazm, 2005/1426.

Abbas, Syahrizal. Manajemen Perguruan Tinggi Beberapa Catatan, Cet. 2; Jakarta, Kencana, 2009.

Al-'Aini, Badr al-Din Abu Muhammad Mahmud ibn Ahmad. 'Umdah al-Qari Syarb Shabih al-Bukbari, ditashhih oleh 'Abdullah Mahmud Muhammad 'Umar, juz 2 Beirut, Dar al-Kutub al-'Ilmiyyah, 2001/1421.

'Ali, Sa'id Isma'il. al-Sunnah al-Nabawiyyah: Ru'yah Tarbawiyyah, Kairo, Dar al-Fikr al-'Arabi, 2002/1423.

Ali, Syed Ameer. The Spirit of Islam, penerj. Margono dan Kamilah Yogyakarta, Navila, 2008.

Amin, Ahmad. Fajr al-Islam, Beirut, Dar al-Kitab al-'Arabi, t.th.

Al-'Asqalani, Ahmad ibn 'Ali. al-Ishabah fi Tamyiz al-Sbahabah, ditahqiq oleh Thaha Muhammad al-Zaini, Kairo, Maktabah Ibn Taimiyah, 1993/1412.

Al-Bukhari, Abu 'Abdullah Muhammad ibn Isma'il. Shahih al-Bukhari, Beirut, Dar Ibn Katsir, 2002/1423. 1998.

Burhanuddin, Yusak. Administrasi Pendidikan, Bandung, Pustaka Setia,

Hart, Michael H., The 100: A Ranking of the Most Influential Persons in History, diterjemahkan oleh Ken Ndaru dan M. Nurul Islam, 100 Tokoh Paling Berpengaruh di Dunia, Jakarta, Noura Books, 2012.

Husain, Abu Lubabah. al-Tarbiyah fi al-Sunnah al-Nabawiyah, Riyadh, Dar al-Liwa, t.th.

Ibn 'Asyur, al-Tahrir wa al-Tanwir, juz 15, al-Maktabah al-Syamilah alIshdar al-Tsani.

Ibn Hajar al-'Asqalani, Ahmad ibn 'Ali. Fath al-Bary, ditahqiq oleh 'Abd al-Qadir Syaibah al-Hamd, Riyadh: 'Abd al-Aziz Ali Sa'ud, t.th.

Jawad, Haifaa A. Otentisitas Hak-bak Perempuan: Perspektif Islam Atas Kesetaraan Jender, terjemah dari The Right of Women in Islam: An Authentic Approach, Yogyakarta, Fajar Pustaka Baru, 2002. 
Al-Mawardi, 'Ali ibn Muhammad ibn Habib. al-Ahkam al-Sulthaniyyah wa al-Wilayat al-Diniyyah, ditahqiq oleh Ahmad Mubarak al-Bagdadi, Kuwait, Maktabah Dar Ibn Qutaibah, 1998/1409.

Al-Mubarakfuri, Shafiy al-Din. al-Rabiq al-Makbtum, t.tp., Maktabah Nur al-Islam, t.th.

Muslim ibn al-Hajjaj al-Qusyairi al-Naisaburi, Abu al-Husain. Shabih Muslim Riyadh, Dar al-Mugni, 1998/1319.

Al-Nawawi, al-Imam. Shabih Muslim bi Syarh al-Nawawi, Mesir, alMathba'ah al-Mishriyyah, 1930/1349.

Pusat Bahasa Departemen Pendidikan Nasional, Kamus Bahasa Indonesia, Jakarta, Pusat Bahasa, 2008.

Sahertian, Piet. Dimensi-dimensi Administrasi Pendidikan di Sekolah, Surabaya, Usaha Nasional, t.th.

Sutarmadi, Ahmad. Meneropong Jejak Rasul: Revitalisasi Hadis, Cet. I; Jakarta, CMB Press, 2008.

Al-Qazwini, Abu 'Abdullah Muhammad ibn Yazid. Sunan Ibn Majah, ditahqiq oleh Muhammad Fu'ad 'Abd al-Baqi, t.p., Dar Ihya al-Kutub al'Arabiyyah, t.th.

Al-Qurthubi, Muhammad ibn Ahmad ibn Abi Bakar. al-Jami' li Abkam al-Qur'an, ditahqiq oleh 'Abdullah ibn 'Abd al-Muhsin al-Turki, Beirut, Muassasah al-Risalah, 2006/1427.

Al-Tirmidzi, Muhammad ibn 'Isa ibn Surah. Sunan al-Tirmizi, dita'liq oleh Muhammad Nashr al-Din al-Albani, Riyadh, Maktabah al-Ma'arif, t.th.

Usman, Husaini. Manajemen: Teori, Praktik, dan Riset Pendidikan, Ed. 3; Jakarta, Bumi Aksara, 2011.

Al-Wahidi al-Naisaburi, 'Ali ibn Ahmad. Asbab al-Nu₹ul, ditakhrij oleh 'Isam ibn 'Abd al-Muhsin al-Humaidan, Saudi, Dar al-Ishlah, 1992/1412.

Wensinck, A.J., al-Mu'jam al-Mufahras li Alfazh al-Hadits al-Nabawi, Leiden: E.J. Brill, 1936.

Al-Yahshabi, 'Iyadh ibn Musa ibn 'Iyadh. Ikmal al-Mu'lim bi Fawaid Muslim, ditahqiq oleh Yahya Isma'il, Mesir, Dar al-Wafa, 1998/1419.

Al-Zarqani, Muhammad 'Abd al-Azhim. Manabil al-Irfan fi Ulum alQur'an, ditahqiq oleh Fawwaz Ahmad Zamrali, Beirut, Dar al-Kitab al-'Arabi, 1995/1415. 